\title{
CRIMINALIZATION OF ALCOHOL CONSUMPTION
}

\section{International Criminal LaW}

Whilst the early system of international criminal law has not directly dealt with the questions of the prohibition of alcohol, there have been certain rules concerning its criminalization under national criminal systems. Historically, certain rules have been regulated to criminalize its importation in certain areas or certain measures have been imposed in order to minimize its distribution. The process of prohibition, criminalization and restrictive possession of alcohol has, for instance, been very long in the United States. A chief justice of one of the courts of the United States has asserted that "And if any State deems the retail and internal traffic in ardent spirits injurious to its citizens, and calculated to produce idleness, vice, or debauchery, I see nothing, in the constitution of the United States to prevent it from regulating and restraining the traffic, or from prohibiting, it altogether, if it thinks proper."' This applied to the prohibition of the sale and manufacture of alcohol. However, the growing development in the twentieth century has changed the position and all these prohibitions have been effectively abolished. A similar conclusion may be presented about the regulations of some other states such as the prohibition in the Russian Empire and Soviet Union during 1914-1925.

The new development in the system of international law may be examined under the Convention on the Rights of Child which aims to express the negative effect of the consumption of alcohol by parents and to impose certain measures on the contracting parties to forbid access to alcohol for children under the age of $16 .^{2}$ For this reason, the Committee on the Rights of the Child recommends that:

${ }^{1} 46$ U.S. (5 How.) 577 (1847). Cited in www.druglibrary.org/schaffer/LIBRARY/ studies/vlr/vlr1.htm.

2 The Committee on the Rights of the Child is "concerned about the harmful effects of alcohol and substance consumption by parents on the physical, emotional and psychological development and well-being of children in the State party. While noting that the Alcohol Act prohibits the selling of alcohol to children aged 16 years or below, the 
... the State party take initiatives to combat drug and alcohol abuse by children, including thorough public education awareness campaigns and ensure that children who abuse alcohol and/or use drugs and other harmful substances have access to effective structures and procedures for treatment, counseling, recovery and reintegration. The Committee further recommends that parents are educated, through, inter alia, awarenessraising campaigns, on the harmful effects of parents' use of alcohol and controlled substances on the development and well-being of children. The Committee urges the State party to adopt the necessary legislation to prohibit the sale, use and trafficking of controlled substances by children, and to ensure the effective implementation of all legislation prohibiting alcohol and substance use by children.

The criminalization of the sale of alcohol to those under a certain age is also recommended by the legislations of many European states such as Sweden, Denmark, Norway and Finland. All these imply the fact that the use of alcohol under a certain age is not recommended and there are rules encouraging its disadvantages for family unity.

\section{ISLAmic International Criminal LAW}

The criminalization of alcoholic drinks is one of the most well-known characterizations of Islamic law. The Qur'ān does however refer to the usefulness of wine, but for the sake of an individual, group or nation drinking alcohol has been prohibited in order to strengthen one's resolution and control, as well as protecting family unities from destruction. The Qur'a $n$ therefore states the prohibition of drinking wine along with its utility and proclaims that 'They ask you concerning wine and gambling. Say: In both of them is great sin or great harm and some advantages for men but their disadvantage is greater than their advantage.' ${ }^{3}$ Another verse reads that ' $\mathrm{O}$ you who have believed! do not offer your prayer when you are intoxicated until you know well what you utter ... ${ }^{4}$ This means that intoxication is the statute that creates an unstable situation for the person who has drunk alcohol or other similar substances or even used drugs.

Committee expresses concern that the Act carries no penalty in the case of violation, and that legislation prohibiting the use of alcohol by minors is generally ineffectively implemented." CRC/C/15/Add.261, 21 December 2005, para. 83.

3 The Qur'ān, 2:219.

4 The Qur'àn, 4:43. 
In another verse the Qur'ān categorizes idolatry and alcoholic drinks as being on the same level. It states that ' $\mathrm{O}$ you who have believed! intoxicants and gambling, set up stones (to worship, to sacrifice) and the divining arrows are an abomination, and are filthy deeds of the evil, insurgent, ignorant and satanic men, therefore refrain from such evil deeds so that you may be successful.' According to the same source, "The evil man or Satan only desires to sow enmity and hatred among you, with intoxicants and gambling, and hinder you from the remembrance of God, and from prayer; will you not then abstain?'

Without doubt, the verses above refer to the criminalization of two different conducts, both of which are against the social structure of human society. These are alcohol and gambling. The system of international criminal law does not however deal directly with these two different types of criminalisation. It is nevertheless a rule within the Convention on the Rights of Child, that children of a young age should be protected from the hazardous effects of alcohol and other harmful social phenomenon.

5 The Qur'ān, 5:90.

6 The Qur'ān, 5:91. 